\begin{abstract}
What happens to the relations involved in forms of ownership when faced with new claims and challenges? This article looks at three examples of the way in which Mongolians are managing claims to resources and responding to new regimes of ownership. In each case, recourse to models of ownership based on masters and custodians are marshalled and extended to suit new contexts. I suggest that these should not be viewed as modern responses to the inequalities of current economic and social life (cf. Comaroff \& Comaroff 1999), nor should they be viewed as a historical remnant from some previous social life. Rather, and here I follow Tsing (2005, 2015), they may be viewed as an outcome of an innovative 'friction', or 'salvage economy', between global and local realities that gives rise to what Gibson-Graham (2006) argue is a heterogeneous capitalist landscape, here manifested in Mongolia's dramatically rising and falling mineral economy.
\end{abstract}

Keywords: capitalism, debt, resources, mining, masters of the land, custodianship, politics, nature, economies of ownership. 


\title{
Claiming Resources, Honouring Debts: The Cosmoeconomics of Mongolia's Mineral Economy
}

\author{
Rebecca Empson, UCL
}

How does a cosmological relationship come to inform different kinds of legal, economic and political engagement in the face of changing claims to resources? This article explores how a specific relationship of ownership is brought to bear on different claims in the midst of Mongolia's booming mineral economy. In 2011, Mongolia was one of the world's fastest growing economies for the fifth year in a row, due to a rapidly growing mining industry involving large-scale mines with foreign investors and largely unregulated, small-scale artisanal mining.

However, the road to economic growth has not been straightforward. Challenges, particularly those surrounding claims to ownership and rights to resources, remain contentious and often unresolved. By 2016 the economy was at a complete standstill with a 'crisis' mounting as personal and national debt grew, with a global decline in the demand for copper and coal, and the slowdown of the Chinese steel industry, leading to a USD 5.5. billion bailout by the IMF (and other development partners) in 2017. This roller coaster of rapid fits and starts is what Mongolians call 'wild capitalism' (zerleg kapitalism). It is characterised by the normalcy of continuous exposure to a frontier market of neoliberal policies, such as soft-loans, debtfinanced public spending, and the rampant mixing of politics and personal business that has come to characterise not only the economy but most of life itself.

This may sound like a familiar story that resonates in other places where the same forms of financialisation have been implemented. However, I want us to be wary of this kind of global comparison and to resist assuming we know what capitalism is and how it manifests (cf. Jacobs and Mazzucato 2016:2). Appeal to this kind of suspension is similar to what some theorists have called the need to avoid resorting to 'capitalocentricism' - that is, forms of thought which represent the economy (or capitalism) as essentially singular and knowable. Instead, and following Gibson-Graham (1996) and others (Roelvink, St. Martin, and GibsonGraham 2015), I want in this article to render visible the non-capitalist diversity that exists within capitalist forms in Mongolia.

More recently, such an approach has been taken up and extended by Tsing (2015a) in her work on 'salvage accumulation' and 'non-scalable economies'. Exploring what she refers to as the '...edges of what can conceivably be called capitalism, where non-capitalist forms of value are constantly being converted into capitalist values' (Tsing, 2015b) ${ }^{\mathrm{i}}$, attending to 'salvage accumulation' is to focus on the process of translating things of non-capitalist value into capitalist value (i.e. as commodities) (Tsing 2015a, 2017). Expanding this approach, Bear et al. (2015) argue for a focus on the range of powers and practices through which people constitute diverse livelihoods as they seek to realise potentialities of resources, money, labour and investment. 'Instead of taking capitalism a priori, as an already determining structure, logic, and trajectory', they '... ask how its social relations are generated out of divergent life projects' (Bear et al. 2015) ${ }^{\mathrm{ii}}$. It is important to highlight that, along the lines argued by Gibson-Graham (2006), this is not a call for the study of alternatives to capitalism, rather it is a plea to attend to the diversity that exist within worlds that we recognise as capitalist. 


\section{Modelling Social Relations}

The social relations surrounding claims to ownership and rights to economic resources that I shall focus on are based on a hierarchical mode of respect that grants 'temporary possession' of the landscape's resources to those who honour it. The Mongolian concept of 'temporary possession' (ezemshil) is based on a pastoral model of land ownership that pivots around herders having access to resources (such as water, pastureland, etc.), but not outright ownership of land, something commonly referred to as 'usufructuary access' (cf. Murphy, 2014:115). Access to resources is granted through a model of 'custodianship' that pivots around a relationship between a 'master' and a 'recipient' (patron-client / noble-commoner). ${ }^{\text {iii }}$ Whereby the recipient is in a position of debt to the master to whom he makes annual offerings, recognising the structural hierarchy that characterises their relationship and thereby perpetuating the usufructuary agreement.

In Mongolia, this relationship is replicated on many different levels or scales, including between the people of a household and the male head, between commoners and the ruling banner aristocrat, the people and the nation or state, and between humans and the spiritual owners or 'lords' of the landscape. Indeed, because of this relationship, it could be said that people are always in a position of debt to some higher authority. I will use the idea of custodianship (rather than private ownership) as a starting point, or provocation, through which to understand the way in which Mongolians have engaged with ideas about access to resources during a period of large-scale mineral extraction in the region. In asking how customary notions of ownership are paralleled and refracted through these practices, I suggest that they provide a lens through which we can understand the way in which access to mineral wealth and other resources is being understood and practised locally.

At this point, I must stress that custodianship is not a residual or 'infantile' mode of ownership. Its presence in what appear to be familiar capitalist neoliberal contexts serves to disrupt our conceptual comfort zones of how capitalism, and especially capitalist property regimes, should appear (see de la Cadena, 2010). Indeed, when people in Mongolia question modes of ownership and extraction, we should not, I argue, view this as a form of 'resource nationalism' (a term often used by foreign investors and media who accuse Mongolians when deals do not go to plan); a kind of conservatism that plagues 'progress' narratives of capitalism. Rather, the prevalence of such practices serves to disrupt our assumptions and provide a challenge to prevalent political and economic narratives of 'progress'.

Understanding diverse models of ownership in this way leads to an ethnographic examination of who can claim rightful access to resources and on what grounds. Examination of these cases allows me to argue that capitalism is not something we should assume we know as a single entity. It is itself inherently diverse and variable. This will be explored through three distinct examples, each of which evokes 'master-custodian' relations. The first involves granting state protection to a sacred mountain. The second involves miners making offerings to masters of the land. The third explores the language of an NGO helping herders in mining areas.

Attending to these examples, I argue, affords insight into the way in which the fits and starts of economic growth and decline associated with the mining industry are being experienced internally in Mongolia. When resources are sought, economic life is not just a series of transactions. Integral cosmological work goes into securing one's share and determining one's fate, so that exchange in the market and cosmological life are one and the same in the production of modern economics. This leads me to a more general discussion of Tsing's 
concept of 'friction' (2004) and 'salvage accumulation' (2015a) and the way in which existing forms of ownership might provide the basis for new kinds of economic engagement to emerge.

\section{Cosmoeconomics and a model for ownership}

In her description of indigenous protests against the mining of a sacred mountain in the Andes, Marisol de la Cadena (2010) invites us to consider opening up politics to universes beyond the human, to allow the agency of sacred mountains into debates concerning access to resource. This, she argues, is not simply an appeal to 'an indigenous mode of being', or an archaic form that needs to be preserved, nor is it a misunderstanding of current capitalist economic life. Instead, it allows us to challenge present political formations and categorisations. In fact, these kinds of voices are often not allowed in politics because politics rests on the separation of nature and humanity, where only humans are allowed a voice. The presence of what de la Cadena calls 'earth-beings' in social protest, thus, invites us to slow down our reasoning, allowing for a rupture with this theory of politics (2010: 343). She reflects: 'caring about earth-beings and place is, of course, not at odds with a desire for economic well-being' (de la Cadena 2010: 356). Indeed, a ' ...pluriversal politics (or a cosmopolitics) would [in fact] accept what we call nature as multiplicity and allow for the conflicting views about that multiplicity into argumentative forums' (2010: 361).

In relation to her call to open up politics to include alternative voices, we should keep in mind that the examples of economic engagement and critique which I focus on are not simply an indigenous response to neoliberal expropriation of minerals, or a 'magical response' to modern inequalities. In Mongolia, such distinctions are never clear, not least because herders have family members who mine and miners have family members who are herders, so that everyone is implicated in some way. While there is no single nature, there is equally no single capitalism, but rather variation within each. Nor should these examples simply be viewed as something that can be seen as the result of a new wave of global 'environmental consciousness', although some have termed it 'national environmentalism', and such groups have emerged (cf. Barria 2013). For most, it is important to stress that it is simply an attempt to keep up political relations (which include cosmological beings) needed to gain access to the means by which life can continue to be lived in this environment.

This idea of nature as integral to politics rather than somehow separate from it, rests on a particular view of nature and politics that I need to delineate in some detail before we turn to our examples. It is through this that we can understand why cosmoeconomics is an important concept for understanding these cases. It is only by grasping the way in which people's relationship to nature is political that we can, in turn, see why mining 'natural' resources (as an economic activity) involves negotiating political relations that include cosmological beings on different levels or scales. In this light we will see that it is through the extraction of natural resources that the economy of Mongolian cosmo-capitalism is organised.

I came to understand what one might refer to as the 'nature' of Mongolian 'nature' through observing pastoral herders' everyday practices, such as daily milk libations (sü̈̈ örgösön / sü̈̈ san serjmee tavisan), as well as through more reflective conversations with my long-term friend, Oyungaa, a full-time diviner. One afternoon, when staying at her house based in a small district in the Northeastern Mongolian countryside, we sat down for some tea and she explained: 
'As you know there is the 'owner of the land and pasture'. We must understand that these owners live in the mountains, hills, plants and trees and they all have their own breath (ami). We have to treat nature in a way as if there is an owner who resides there which protects it. We should not anger this owner'.

Attending to the idea that nature has an 'owner' or 'master' is to acknowledge an animate landscape that demands a particular kind of political engagement from the people who live on its surface. Commonly known as the 'lords' or 'masters of the land' (gararyn ezen) ${ }^{\mathrm{iv}}$, these agents bestow fortune and generosity (hishig) to people who honour and observe them. Specific types of relations are, thus, developed to manage and sometimes maximise the effects that can be gleaned through such human / non-human interactions (cf. Humphrey with Onon 1996: 52). ${ }^{\mathrm{V}}$ Daily offerings of milk libations to the masters of the land, secure the water, pasture and weather needed to raise one's family and herds, and not observing this relationship can lead to the masters of the landscape becoming angered. Such anger, the local diviner went on to explain, can manifest itself in:

'Flooding, hail storms, lightening, and so on... one should not throw anything nasty into the rivers and streams, should not break trees, move stones or dig in the ground, we should protect the environment.'

Masters of the land reprimand as well as give; punish as well as reward, so that even hunters or miners who might reap illicit rewards from the landscape offer some choice portion so that nature will give them its fortune / generosity in return. It is worth noting that the relationship is not one of simple exchange but points to a kind of innate hierarchy; one has to show deference and respect to the other with whom one is intimately connected and dependent upon. In attending to such a relationship, the Mongolian landscape becomes an interactive field of engagement rather than a passive background setting from which resources can be extracted and on which human action takes place. Land and people are always in a process of mutual definition so that people are, in fact, the custodians of the land on which they live.

The idea that people do not own but are in a relationship with the landscape is evidenced most clearly perhaps at annual mountain ceremonies or sacrifices (tahilga, lit. to make an offering or sacrifice) at sacred cairns (ovoos) where people gather in the early summer to ensure seasonal rainfall and fertile livestock. ${ }^{\mathrm{vi}}$ It is through these ceremonies that people publically honour their debt to the local 'land masters' / 'master's of the land' (uulyn ezed) and receive the fecundity and protection that allows them to live near its base. ${ }^{\text {vii }}$ Writing about this ceremony, Sneath (2001) has noted that it is an occasion for the 'political architecture' of the district or province to be enacted (Sneath 2001: 46). He stresses that people who attend the ceremony should not be viewed as the owners of the land on which they live. Instead, "[i]ndigenous Mongolian notions of "land ownership" can be described as "custodial" in that [people have] conditional rights to use territory and always within a wider sociopolitical framework' (Sneath 2001: 43). Such socio-political frameworks have, of course, varied historically (see below) but they have also, on a cosmological level, very much remained the same. Even at the end of the seventeenth century, when Mongolia came under the control of the Manchu (or Qing dynasty), '[i]mperial and princely jurisdiction over land [was] subject to the approval of yet higher authorities' (Sneath 2001: 45). These 'higher authorities' were the ever-present, yet always highly unelaborated, 'masters' or 'lords of the land' (gazryn ezed). Considered to have control over human prosperity, rain, the elimination of calamities, diseases, storms, and the flourishing of domestic livestock in each locality, they bestow fortune on the land. 
It is here that we can see how politics and nature are co-dependent, scaling each other through a particular relation. The term 'ezen' (singular of ezed) is usually translated as 'owner', but also means 'lord', 'head', or 'master', and is used to denote asymmetrical relations entailing hierarchy and obligation at several different scales or levels. For example, the word 'master' (ezen) was used for socialist and pre-socialist temporal rulers (Humphrey with Onon 1996), the eldest male of a household, the head of a factory or other large-scale enterprise, and in the past, for the polity (Sneath 2001: 47). Like the portion of milk offered to the masters of the land in libations, the first portion of hot food, usually prepared once a day, is given to the eldest male of the household, ensuring that the choicest/ sacred portion (deej) is reserved for the 'master of the house' (geriin ezen).

Offerings such as these draw attention to the idea that people are not the absolute owners but the 'custodians' of the land on which they live (Sneath 2002). The dynamic of this relationship can be said to provide a model for more general ideas about power and authority between master (patron) and custodian (client) and the kinds of exchange such relations engender. For example, the relationship of master and custodian has been taken up by various figures of authority at different historical junctures in Mongolia, be that between the local noble / aristocrat and his commoner people, or the socialist state and its citizens, and points to more widespread ideas about power and who can wield it. It illuminates a kind of fractal view of nested hierarchies across different scales.

People are, thus, dependent on relations with human figures of authority, as well as with the invisible masters of particular places. Indeed, people seem to ' ... not hold land as they do other mundane possessions, but enter into relations with the spiritual powers of the locality to ensure favourable conditions' (Sneath 2001: 46). Making offerings at local ovoos is a means by which different interest groups - miners, herder, local politicians and traders - can all visibly enact their 'good relations with such spiritual stewards of the land' (Sneath 2001: 46). Offerings to the masters of the land may, thus, be viewed as an expression of an ongoing relationship based on debt and patronage.

Not only is politics infused with what we might assume to be nature, but nature is also always inherently political. The 'temporary possession of land' (ezemshil) differs from market-driven notions of outright ownership based on the idea of individual private property (ömchlöl / khöröngö). While forms of land privatisation are available, particularly in cities and district centres where plots are given and may be used as collateral against loans, pastureland (apart from some kinds of winter encampment) is still accessed under the usufructuary model. As one herder put it to me:

'To sell the pastureland is wrong. It is difficult to understand for Mongolians. For example, [this man] and I live as neighbours, but our animals don't have computers in their heads, my animals will eat from his land and his animals will eat from my land. The cattle will just eat whichever grass is better. If I owned the land I would have the right to expel his animals then they would have no place to go'.

The current Land Law in Mongolia posits two radically different forms of land ownership for private companies (including mine owners) and for herders. Herders are in a good position when it comes to legal protection of their access to resources, but complications can arise when they look for compensation. While land for tenure may be held in ownership (Article 5 (5.1), pastureland, water points in pasturelands, wells, land with forest, and water resources are under government regulation and may be used in temporary possession by people (Article 
6 (2.1-2.5). However, foreign citizens and organisations may only become users of land for a specific time period (Article 6 (6.3)).

Furthermore, the land's resources are not just confined to raising herds; that movable resource that feeds off and is dependent on the communal property regime of usufructuary rights to resources. Indeed, people are always in a position of temporary custodianship (or precarious ownership) to these various kinds of higher orders or 'masters' (see Empson, 2014). This relationship also extends in constitutional prescriptions (of nature into politics) that require a partnership between the State and the people for due care of the country's environment and resources. For example, the State is required to protect the 'national wealth' of inter alia livestock (Article 5(5)), land, water, subsoil, and natural resources (Article 16(1)). In turn, it is the 'sacred duty' of citizens to protect nature and the environment (Article 17(2)) and citizens have the corresponding 'right to be protected against environmental pollution and ecological imbalance' (Article 16(2)).

In the practice of mining, nature as a resource cannot fail but be imbued with diverse cosmological relations. As an economic activity, it is always shaped by its politicocosmological roots. In this sense, the mineral economy in Mongolia is never purely 'market driven', but also, at times, determined by the cosmological and political underpinnings of which it is a part. In detailing the intricate ways in which nature, economics and politics are co-dependent in a cosmology that pivots around masters / custodians, I hope to highlight that the landscape is both a place where resources from nature are sought to grow one's animals in order to live, as well as an interactive and animate place that demands particular kinds of engagement with the people who live there. This is a model of ownership, a cosmoeconomy so to speak, that is enshrined in law and extends to different scales or levels of protection and access. ${ }^{\text {viii }}$

\section{Accessing Resources}

I turn now to three different ways in which people have claimed access to natural resources in different regions of Mongolia. The first example involves herders claiming access to pastureland in the face of pollution by a mining company. The second concerns informal gold miners claiming access to gold through honouring debts to masters of the land. The third and final example examines claims for compensation through a local NGO when resources have been denied to herders. These examples provide contrasting snapshots of new ways of engaging with the landscape and how these ways of mobilising claims and capacities can be carried out through existing models of ownership. ${ }^{\text {ix }}$ A tension between similarity and difference is thus established which produces a kind of 'friction', not unlike that described by Tsing (2005), but also, and I think crucially, attention to this is a way of highlighting the diversity that exists in the shadow of capitalist relations (cf. Roelvink, St. Martin \& GibsonGraham 2015).

\section{I - Making Mountains Sacred}

In an article documenting the activities of a local resistance movement that was formed in response to threats imposed by gold mining, Dalaibuyan Byambajav (2012) shows how herders drew on cosmological notions about sacred mountains and land owners to curtail mining activities. Here a recent mining programme prompted local people to mobilise a range of different strategies to define themselves as the 'rightful' custodians of a place. This 
involved them ultimately seeking protection of the landscape through the state by registering their mountain as 'sacred'.

I focus on this example because this kind of activism may be taken as a more general example of the way in which cosmological (one might even say spiritual) perspectives are marshalled as defensive strategies against changing political and legal landscapes that (attempt to) silence and exclude the perspectives of those who live there. Amplifying the sound of these people's voices and attending to their innovative cosmo-visions, new and emerging subjects are brought into focus as ones who have rightful access to the landscape, as well as new visions of what might count as the political.

In his account, Byambajav (2012) details that in a small district in central Mongolia in 2005 local residents engaged in a road-block to prevent ongoing mining in their region. Mining in this area had been happening since 1999 and local people had been involved in putting together petitions, had put up resistance by refusing to move from pastureland and had staged sit-ins on mining sites, as well as engaging in outright physical conflict with miners. In capitalist terms, Byambajav (2012) argues that despite these political activities, the local herders loss of access to their material base of livelihood (i.e. to their pastureland), could be viewed as a form of 'dispossession', preventing their rights to access their 'indigenous' land and environmental resources. As we know, however, and as I explained earlier, such a model of land ownership is not prevalent in this context, so in order for local people to make a case against the development of mining in their region, they had to evidence their longstanding spiritual, genealogical and socio-economic connections to the place.

The mountain Suvraga Hairhan is famous for its pristine environment and unique landscape. Local herders worship the mountain as a sacred, protective entity and hold ovoo ceremonies there. After several attempts to prevent mining exploration taking place in this area, the herders turned to their 'local homeland council' (Nutgiin Zövlöl). This council is composed of urban citizens who form an extended community of people from the same place or district (neg sumynhan) and provide financial and social support to their homeland. In 2005, local people, including politicians and administrators as well as people from the homeland council, formed an organisation (the Ariun Suvraga Movement) to address the increasing impact of mining in the district. They organised a series of events and responses, including forming a three-month long road barricade on the road through a valley which was to be mined, a kind of collective political activity that is quite unique for rural areas in Mongolia.

With the assistance of a lawyer, they filed a lawsuit against the mining company, arguing that several rivers in the area had dried up, the mining company had not paid water usage fees, nor had they approved their environmental protection plan. ${ }^{\mathrm{x}}$ After much debate, their case was defeated at all three levels of the court and the case decided in favour of the mining company continuing its activities (albeit in a slightly smaller area than before). Byambajav (2012) speculates that this decision may have been swayed by the fact that the mining company had promised a certain percentage of their income to the district and the local government. While the herders left their barricade to resume their normal lives and mining activities continued, no one could deny the ongoing environmental impact in the district.

Frustrated and worried, by 2007 the herders had turned to another means by which to regulate the mining activity in their region. 'In 2007 [Byambajav describes], Mount Suvraga Hairhan was approved as a state worshipped mountain' (Byambajav 2012: 27). Even though worshipped mountains were not legally outside those areas permitted for mining, granting 
state protection of the mountain was regarded as a new, and innovative, way to protect the environment from mining operations. Since the end of socialism in Mongolia, eight mountains have been granted the status of 'State-Worshipped Sacred Mountains' (Ulson Tahilgat $U u l$ ) across the country. Every four years, the President of Mongolia takes part in the ritual worship of these mountains for the protection of the state and its people. ${ }^{x i} \mathrm{By}$ establishing their mountain as a State-Worshipped Sacred Mountain, the herders in Byambajav's case were able to ingeniously prevent any mining taking place at the source of their rivers and forests: exactly those places that needed protection from environmental degradation in order to preserve their pasture and exactly those places deemed 'sacred' according to the worship of local masters of the land and their sacred cairns.

What we can observe in this example is, I think, the way in which various concepts, frameworks and ideas (the cosmological infrastructure, so to speak) can come to assist people as a sort of toolbox in their campaign to recognise some kind of right to access resources in the landscape in which they live. While the situation is complex (especially because claims are most often based on usufruct), and continues to be so, with local and national power holders' interests interwoven with mining, allies were sought and urban-rural networks were established to mobilise recognition. What this example highlights, then, is the way in which local actors applied different 'cultural' practices, drawing on a range of cosmological, legal and political frameworks, to mobilise action and to set in motion, or maybe bring into being, their particular version of what the landscape was and should be. Byambajav (2012) argues that these practices may themselves be viewed as 'different social and cultural resources and practices that encourage bonds and collaboration among people' (Byambajav 2012: 28). I think we can also conceive of them as interesting intersections where seemingly 'nonscalable economies' (such as mountain worship) come to penetrate legal and political frameworks that seem antithetical to them, thereby shaping them from within.

It should be clear by now that while mining benefits many, it also has long-term effects on the communities of people (i.e. herders) who do not own the land that such companies use as private property. In the face of on-going widespread environmental degradation, local people are often at a loss (both legally, as well as politically) as to how to retain access to the land's resources which they depend on for their livelihoods. The small district described by Byambajav received little direct benefit from the mineral extraction, which continues to go on. When their custodianship was threatened, there was little basis on which they could claim ownership over any resources. With no private land ownership of pastureland, the herders had to present themselves as the long-term users of a place with rights to resources established over generations rather than through legal contracts. This differentiated connection to place was put forward by the local homeland council representatives in legal courts as the ground for claims to resources.

Despite this innovation, it failed to secure the end of mining activities in their region. In the end, the herders mobilised themselves as people whose ancestors had worshipped the land masters of this place over generations. Thus, the long-term presence was not just linked to use of resources, but to the ongoing relationship of custodianship with the spiritual lords or masters of the place in which those resources are made available to people. In making this relationship visible, they were recognised as the rightful guardians (ezen) of the scared mountain and sought protection from the state, who recognised it as such.

In terms of cosmological transformation, the encounter between the mining company, local herders and claims to different resources in the landscape prompted a new way of thinking 
about the landscape, not just regarding mining, but also regarding the way the herders saw the spiritual nature of the landscape. This is illustrated by the fact that, after various avenues of protest had not deterred the miners (including blocking the road, legal protection, etc.), local people resorted to a third, and possibly more powerful, form of deterrent; registering their mountain as one of the eight sacred mountains in Mongolia. It is worth noting that this recognition came about as an outcome of dealing with disputes over access to resources. Indeed, one might say that local herders sought state protection of the sacred not as a last resort to cultural logics, but as an outcome or 'friction' with the mining companies' activities based on the logistics of private property ownership, forcing them to mobilise an even more modern form of ownership - state protection of the sacred.

\section{II - New masters for new practices}

My second example examines offerings made by people who work as informal gold miners in central Mongolia. Here, the distinction between what is new and what is old is blurred in terms of cosmological engagement. While the previous example pitted herders against miners in their views of the landscape, its resources and economic capacities, most people in Mongolia are, in fact, dependent on funds generated through informal mining in some way, even if that be through extended family networks. Indeed, High (2013) has stated that ' $[\mathrm{h}]$ erders and miners, city dwellers and countrymen are all likely to be implicated in mining, either directly or indirectly'. Drawing on her ethnography, we see that the economy of temporary possession, and its corresponding master-custodian relationship, far from being excluded or ignored in mining activities actually extends into the sphere of mining. Here then is an example of ideas about 'nature' being extended to a context that one would normally think of as 'purified' of such concerns.

Documenting the interdependence of herding and informal gold-mining in central Mongolia, Mette High (2013) notes rumours that circulated throughout Mongolia in 2002 regarding new ways of dealing with the masters of the landscape by miners. All around Mongolia, she describes how rumours circulated that informal miners were sacrificing human blood to appease the spirits of the landscape in mining areas. On mountains surrounding mines, traces of blood rather than milk were seen having been used in sacrifice and this, along with accounts of people waking to find themselves covered in cuts, was held as evidence that informal miners had resorted to human blood sacrifice to appease local spirits. Was this an all too familiar expression of what some anthropologists have termed an 'occult economy' (Comaroffs, 1999) where blood had become the 'currency' that mediates new human desires and hungry spirits; a cosmological transformation triggered as an outcome of rapid political and economic change?

As we have seen, local concepts of pastureland demand that people engage in particular kinds of practices which are regarded as respectful (hündetgeh). Digging the ground is traditionally thought of as prohibited. Mining requires people to engage with the land in a new way, since people need to show respect in spite of their infraction. Like hunters, the bounty given by the land as gold for miners is an expression of the general (hishig) fortune / generosity of the spirits. But normal offerings, High (2013) argues, in the form of milk libations are not enough and, attending to the explanations offered by miners, we learn that extraordinary means are sought. Here, rumours of human blood become the currency by which to appease the 'spirits'. Spirits appeased through blood sacrifices, High learnt, were not to be viewed as regular masters of the land that reside on the land's surface or in mountain cairns. Miners explained to High (2013) that the masters of the land who accepted their blood sacrifices were the so- 
called 'black land masters' who reside substantially lower under the ground and are held to have become visible only through the activities of the gold rush. Rather than the "white spirits' who reside on the surface, then, they do not reside in the mountains' rivers and trees, but in the dank and dark crevices eked out by the miners through their work deep underground.

Exposing a new cosmological realm (i.e. a whole different 'level' of spirits) through their work, these miners point to what High (2013) calls 'a different engagement with spiritual existences'. ${ }^{1}$ Instead of seeking to minimise harmful interactions with the landscape as in the example above, here we see how miners attempt to bargain with masters of the land, asking for reward and forgiveness due to their infractions. How far they manage to appease the cosmos while reaping the rewards of their work is unknowable but the dangers of excessive accumulation may well put a stop to the turns of fortune involved in informal mining for particularly lucky individuals (cf. Empson, 2012). At the same time, I think we can see through this example a kind of continuum of the master-custodian relationship maintained by herders. Indeed, most herders occasionally have to 'trick' the masters of the land into giving them something. The way hunters trick the masters of the land into giving them prey is, for example, similar to the kind of sacrifice made by informal gold miners to the black masters of the land who reside underground to ensure they may receive some gold in return. Explained by my diviner friend as a way to secure hunting luck, she commented that:

'Those who go hunting would plead with nature before they left by saying: "we are victims of life's whims and just want to get some food or berries" and they would offer the select portion of their meal to nature and then nature would offer them its hishig (fortune generosity). Without this, people may receive curses from spirits which could leave them blind or deaf or give them pains which they may suffer from for the rest of their lives.'

In making this comparison, I am not suggesting that the cosmological remains the same while the mundane world changes. Rather what I want to highlight is the way in which cosmological life continues to extend into and interact with the mundane, which is itself always changing. In fact, because these spheres are independent rather than separate, this interaction is not something people attend to in the hope that it will influence their turns of fortune. It actually loops back to become the ground that determines current economic life. In this sense, we may speak of current mining activities as born out of, and not simply a background that gives rise to, a renewed attention to cosmological concerns with an animate nature. The residual 'non-scalable' relations between people and the masters of the land (to use Tsing's term, 2015) persist and are not wiped out by capitalist forms of accumulation providing instead a latent resource or potential. While, at times, this latent resource is considered a potential, it can, of course, equally provide a hindrance and blockage to the flows of fortune that may be generated from the friction and discord that such interaction also generates. In this back and forth, we see that the cosmoeconomy of mining invokes risks whose outcomes cannot be anticipated or known.

\section{III- Compensation claims}

Environmental organisations are also exploring new means to raise awareness of the environmental issues caused by mining in Mongolia. On the morning of the $16^{\text {th }}$ September,

\footnotetext{
${ }^{1}$ See also High (2016) who highlights that when monks are miners the assumed opposition between traditional and extractive economies are very much tested and transcended.
} 
2013, for example, eleven NGOs protested outside the Government Palace against proposed amendments to the Extraction Law on River Basin and Forested Areas. ${ }^{\text {xii }}$ This law was approved in 2009 and prohibits mining operations at the headwaters of rivers, protected zones of water bodies and forested areas (Byambajav, forthcoming). While the amendments were under discussion in a parliamentary meeting, the protest aimed to raise awareness of the destruction to the Mongolian countryside caused by mining. Despite the 2009 law which was meant to preserve the integrity of Mongolia's environment, many protected lands have been mined. Placards were raised around the Government Palace stating: "Around 40 percent of Mongolian territory should be protected by the state and 1,782 extraction permits should be terminated in accordance with the current Extraction Law on River Basins and Forested Areas" (Zoljargal, 2013). Thirty minutes into the protest, a gunshot was heard in the public park behind the Government Palace and the security division of the palace announced an emergency lockdown. Searching the surrounding park, police found several weapons and grenades. The NGOs claim no violence was intended; a blank shot was simply fired to gain publicity.

While some of these NGOs seek to promote what they refer to as 'responsible mining', others demand more radical reforms, which include a legal ban on mining in river basins (see Byambajav forthcoming). This more radical claim has meant that certain nationalist movements in Mongolia have begun to align themselves with environmentalist agendas. ${ }^{\text {xii }}$ They draw analogies between the fear of 'foreign' miners extracting Mongolia's resources and Mongolian women marrying foreign men. Both minerals and women, it is feared, are crossing borders, spawning offspring of unknown origins, which will lead to the decline or disappearance of Mongolia (cf. Bille, 2014). Like the fear of gold mining during the Qing period, there is a fear of the land becoming polluted with incoming miners conducting intrusive behaviour. As in Indonesia and elsewhere, the rise of national environmental movements has become the vehicle for many, sometimes contradictory, hopes as well as fears (Tsing, 2005:17).

An example of this kind of contradictory co-existence is evidenced in the work of a grassroots environmental NGO concerned with the effects of a large foreign-owned mine on local herders. This NGO, run by a Mongolian woman based close to the mine, acts as an advisor to local herders whose pasture and access to water have been affected by the diversion of a local river by the mine. Meeting with the mine's representatives and monitoring their compliance with 'international environmental and human rights standards', they seek to evaluate the impact of the mining activity on the herders.

However, international standards of good mining practice do not always align with local demands and expectations: sometimes exceeding them and sometimes failing to meet them entirely. Meeting 'international standards' does not always chime with local definitions and understandings of ownership, which may have been established in, for example, Papua New Guinea, where clans' rights are tied to plots and gardens over generations, a situation markedly different from pastoral herding practices in Mongolia. ${ }^{2}$ It is difficult to imagine how this NGO negotiated ownership over something that was actually held by the herders as usufructuary custodians.

\footnotetext{
${ }^{2}$ See, for instance, negotiations over the 'Law with the Long Name': https://medium.com/@FrontLineDefenders/mongolia-new-frontier-for-an-old-industrye234d57202d5\#.edfc45ae5.
} 
When common access to resources, such as water or pasture, are challenged and affect the way people can earn their livelihoods, on what grounds might these people seek

compensation? Indeed, what should count as adequate or appropriate compensation for loss of access to pasture, when pasture is not owned by the herders themselves? The idea that 'herders' should be 'compensated' for resources extracted by mining companies that hold licences issued by the state to mine and that their right to pasture should be legalised as private ownership are all new and potentially transformative ways of perceiving usufructuary rights. It remains to be seen how far this framework of claims of 'loss of ownership' can be mobilised, and who will actually come to benefit from such claims. It has, for example, been assumed that one person from each family whose pasture has been affected by mining operations has been awarded a permanent job at the mine. An idea of compensation which might in turn facilitate expanding relationships with the masters of the land through mining, as we saw in the previous example.

\section{Cosmo/pluriversal economics}

Does the fact that people continue to honour relations with masters of the land in order to access resources in the landscape mean that they have 'reverted' to, or are stuck in, former historical practices which were prevalent prior to socialism in Mongolia? Through the three different examples presented in this chapter, I hope to have shown that this is precisely not the case. For a start, people most certainly made offerings to masters of the land during the socialist period on a daily basis. Secondly, cosmological practices such as honouring debts to masters of the land are not, I have argued, an archaic expression of past beliefs now mostly disconnected to the life-worlds of subjects struggling to survive in late capitalism.

Rather, through these examples, we have seen that honouring these relations provides the motivation for change, so that these ways of attending to the landscape and conceiving of ownership are the ground from which current economic forms are being made to appear. This kind of argument is not unlike that put forward by Tsing (2015a) regarding what she terms 'salvage accumulation' or her idea of 'non-scalable economies' which create social relationships that determine people's worlds, even though they may not scale up into capitalist narratives of 'progress'. In fact, if, as she invites us to, we look at the peripheries of capitalist production, putting unpredictable encounters and experiences at the centre of things, we can begin to destabilise categories that we have thought of as fixed, such as pre- or postcapitalist economies, or even, as I mentioned in the opening of this article, capitalism itself.

Similarly, but from a slightly different angle, nor should we see recourse to these relations as a way in which people are making sense of the alienating and disorientating pace of capitalism as it sweeps across the world becoming a global force. This kind of conclusion is reminiscent of the Comaroff's argument in their 1999 article 'Occult Economies' where they called on anthropologists to pay attention to '...the mechanisms by which the local is globalized and the global localized.' (Comaroff \& Comaroff, 1999: 295). In postcolonial South Africa, they argued, the practice of witchcraft '...does not imply an iteration of, a retreat into, "Tradition"" [...] 'On the contrary, it is often a mode of producing new forms of consciousness; of expressing discontent with modernity and dealing with its deformities'. In short, beliefs such as witchcraft are a means of retooling culturally familiar technologies as new means for new ends (Comaroff \& Comaroff 1999: 284, italic in original). Thereby providing a '[...] new magic for new situations' (Comaroffs, 1999: 284). They are keen to stress that it is not an 'African phenomenon'. Such enchanted phenomenon, they argue strongly, are 'modes of producing value' (Comaroff \& Comaroff 1999: 286). So that the most 
vehement enchantments occur where '...raw inequality has become most blatant' (Comaroffs, 1999: 288)

In contrast, the argument I am putting forward does not suggest that recourse to a social relationship with masters of the landscape is born out of and propagated through experiences of marginalisation and inequality (a kind of top-down explanation). This is absolutely not how people explain things themselves (cf. Englund and Leach, 2000). That would be to make connections (a meta-narrative) between entities that were not being made by the people themselves. Englund and Leach (2000) argue that this kind of need to situate the particular in wider (perhaps global) contexts undermines what is unique to the ethnographic method, i.e. the chance to give subjects authority in determining the contexts of their beliefs and practices. The current 'meta-narrative of modernity' propagated by such forms of explanation organises ethnography with its specific emphasis on ruptures and obstructs the production of anthropological knowledge. Drawing such top-down connections between local and global is also strongly reminiscent of what has more recently been called 'dark anthropology' (Ortner, 2016) or a preoccupation with what Robbins has termed the 'suffering subject' (Robbins, 2013), where people everywhere are simply subjected to the inimical forces of neoliberalism which are the same everywhere, leading to a kind of dead-end 'misery porn' where ideas of hope and pre-figurative subjectivity are constantly thwarted.

I would suggest that quite the opposite has been shown to be the case here. Relations of custodianship are nurtured and maintained because they are highly valued and put people at the centre of their worlds in ways that ignoring such relations would not. This is to suggest that these forms are not outside of, or additions to, what we understand capitalism to be: variations of a cultural order that are add-ons due to exploitation and marginalisation of neoliberal practices. ${ }^{3}$ They are, in fact, internal to the diversity that is capitalism. Attending to such relations is an acutely political practice because it shapes people as individuals within a political and economic arena that also highlights ideas of progress and monetary wealth.

The experience of rapid political and economic change and uncertainty due to widespread mining does not simply give rise to cosmological concerns. These are not ways in which people turn to magical means for material ends ( la Comaroffs, 1999). Instead, these concerns emerge out of creative 'friction' or overlap with different cosmological economies. This is a point that has forcibly been made by Tsing (2005) in her work on the changing forestry industry in Indonesia. Here, global interconnections lead to creative expressions, awkward connections and discontinuities of fear and hope where the form of capitalist expansion is not inevitable. Rather, through the 'friction' of local and global forms, new worlds come into being.

In Mongolia, this is a world in which partial connections are made between pre-modern relations and current environmentalist concerns, between forms of capitalism and other forms of ownership, between landscapes conceived as an economic resource and landscapes conceived as an agent. Attending to these connections and disconnections is not something that can be explained as standing for more fundamental material (economic) relations, nor as

\footnotetext{
${ }^{3}$ This is not, as one reviewer of this article put it, to promote a kind of 'ontological pornography of resilience [...] while the landscape is being ruined, social relations thwarted, ownership alienated.' It is to highlight the heterogeneity and difference experienced by people exposed to similar global processes and shifts associated with neoliberal practices the world over. Amplifying such difference is a political act on behalf of the people I work with as much as by myself as an anthropologist.
} 
an outcome of some closed cosmo-ontological realm. It is changing and shaping the economic and political world that emerges from its very surface. Here economic realities are always diverse, containing within them diversions from the norm which sometimes come to shoot off and shape the ordinary. Indeed, it is such diversions from what might be termed 'market relations' that come to determine the economy in more ways than one might anticipate. Resources in nature are not simply to be plucked from the ground, excavating requires managing several strata of relations with others before one can mine. It is in managing these relations that the economy is shaped and determined as much as through the simple sale of the minerals once extracted. Where then does one economy end and the other begin? What reach does a cosmological relationship have when its borders are continually being stretched or concealed? While the economy in Mongolia may be heavily dependent on the push and pull of Chinese demand for raw materials, it is also through the mobilising and enacting of such ideas of ownership as I outlined in this article that Mongolia's mineral economy is being shaped and made.

\section{Conclusion}

I hope to have shown why we must not assume that just because the forms of structural inequality and kinds of financialisation are similar in different parts of the world, we know exactly what capitalism is. This kind of approach is something that has recently been highlighted by Ellis (2013) in his work on the way in which Mongolian shamanic cosmologies spread beyond the context of shamanism. Based on ethnography from a shamanic workshop that makes costumes in Mongolia's capital, Ellis (2013) notes that, among other things, the inclusion of hundreds of material snakes on shamanic costumes has increased in recent years. The tailors in the workshop attribute this to the fact that ancestral spirits are asking for their increase because snakes are animals that crawl upon the ground and are spiritually connected to the earth. The increasing demand for snakes from the ancestral spirits is a direct result of a huge increase in construction and mining work, both of which require digging (Ellis, 2013). One could argue that the changing design of the shamanic costume is simply an expression of concerns about the rapidly changing economic context of Mongolia. Here, political and economic change gives rise to new cosmological ideas. However, Ellis skilfully shows that this is not simply one-way traffic. Political and economic life may also be seen as an expression or an outcome of more fundamental cosmological realities, where work by shamans with ancestral spirits actually comes to shape economic and political life itself.

In line with this kind of approach, I have presented the way in which a concept of ownership, based on the relationship between a spiritual master and a human custodian, comes to influence sacred, political, and environmental registers, determining the material realities and resources of people's everyday lives. Emerging through collaborative friction, we see that economic and cosmological (or political and natural) life are one and the same. This collaborative overlay is not simply an outcome of neo-liberal uncertainty, but a unique way of understanding the form that capitalism can and does take in this context. Including cosmological nature relations in our understanding of economics and politics might be a challenge to homogenising models of global capitalism. It is to turn away, perhaps, from formal models of progress toward a wider field of engagement that recognises the heterogeneous and creative articulations that give rise to current economic realities and understandings of ownership. Rather than see these as 'outside of', or counter to, capitalism, then, I follow Gibson-Graham (2006) in arguing that such existing economic diversity is what capitalism depends on. This, then, is an attempt not just to show what has become hegemonic 
(i.e. neoliberal features penetrating social life making it the same everywhere), but to illuminate the diversity within capitalism; to make existing economic diversity visible.

\section{Acknowledgements}

My sincere thanks to Giovanni and Nils for putting this special issue together, and to Giovanni for organising the AAA panel on which we initially presented some of the ideas. I also thank the Emerging Subjects Project at UCL and MNU, including Bumochir Dulam, Lauren Bonilla, Hedwig Waters, Rebekah Plueckhahn, Liz Fox, Joseph Bristely, Hermione Spriggs, Tsetsegjargal Tseden, Byambabaatar Ichinkhorloo, Bayartsetseg Terbish, MunkhErdene Gantulga, Tuya Shagdar, Narantuya Chuluunbat, Marissa Smith, Sanchir Jargalsaikhan, Badruun Gardi, Haltar Batsuuri, Uranchimeg Ujeed, and Erdenezaya Batbayar for crucial discussions and debates along the way. Thanks also to Mette High, Byambajav Dalaibuyan, and Joe Ellis for their inspiring ethnographic accounts that I draw on here. The gap between writing and publication was a long one and things have changed in ethnographic reality and my intellectual thinking since this paper was first drafted. The research for this paper has been funded by ERC-2013-CoG, 615785, Emerging Subjects. 


\section{Bibliography}

Atwood, Christopher P. 2012 Banner, Otog, Thousand: Appanage Communities as the Basic Unit of Traditional Mongolian Society, Mongolian Studies, 34 (2012),

Atwood, Christopher, P. 2005 State Service, Lineage and Locality in Hulun Buir, East Asian History, no 30 (Dec 2005), 5-22.

Barria, Carlos 2013 Mongolia neo-Nazis announce a change of track - pollution control, Reuters, $2^{\text {nd }}$ July, 2013, www.reuters.com/article/2013/07/02/us-mongolia-rightwingidUSBRE96108N20130702

Bear, Laura, Ho, Karen, Tsing, Anna and Yanagisako, Sylvia, 2015 Gens: A Feminist Manifesto for the Study of Capitalism, in Theorizing the Contemporary, Cultural Anthropology website, March 30, 2015. https://culanth.org/fieldsights/656-salvageaccumulation-or-the-structural-effects-of-capitalist-generativity

Bille, Franck 2014 Sinophobia: Anxiety, Violence, and the Making of Mongolian Identity, Hawai'i: University of Hawai'I Press

Byambajav, Dalaibuyan 2012 Mobilizing against Dispossession: gold mining and a Local Resistance Movement in Mongolia, Journal of the Center for Northern Humanities, No 5, 1332 .

Byambajav, Dalabuyan forthcoming The River Movements' Struggle in Mongolia, Social Movements Studies.

Comaroff, Jean and Comaroff, John. L (referenced as Comaroffs) 1999 Occult Economies and the Violence of Abstraction: Notes from the South African Postcolony American Ethnologist, Vol. 26, No. 2 (May, 1999), pp. 279-303

De la Cadena, Marisol 2010 Indigenous Cosmopolitics in the Andes: Conceptual Reflections beyond 'Politics', Cultural Anthropology, Vol. 25, Issue 2, 334-370.

Ellis, Joe 2013 Assembling Contexts: The Making of Political-Economic Potentials in a Shamanic Workshop in Ulaanbaatar, MRes Dissertation, UCL Anthropology Department.

Empson, Rebecca 2014 An Economy of Temporary Possession, Malinowski Memorial Lecture

Empson, Rebecca 2012 The Dangers of Excess: Accumulating and Dispersing Fortune in Mongolia, Social Analysis, Volume 56, Issue 1. Spring 2012, pp117-132

Empson, Rebecca 2011 Harnessing Fortune: Personhood, Memory and Place in Mongolia, Oxford: Oxford University Press

Englund, Harri and Leach, James 2000 Ethnography and the Meta- Narratives of Modernity Current Anthropology, Vol. 41, No. 2 (April 2000), pp. 225-248

Gibson-Graham, J.K. 2006 APostcapitalist Politics Minnesota: Minnesota University Press 
Gibson-Graham, J.K. 1996 The End of Capitalism: (as we knew it): a feminist critique of political economy, Oxford: Blackwell

High, Mette M. and Schlesinger, J. 2010 Rulers and Rascals: The Politics of Gold in Qing History, Central Asian Survey, 29:3, 289-304

High, Mette 2013 Believing in Spirits, Doubting the cosmos: Religious Reflexivity in the Mongolian gold mines, ethnographies of Doubt: Faith and Uncertainty in Contemporary Societies, (M. Pelkmans eds) pp 59-84, London: I.B. Tauris.

High, Mette 2016 A Question of Ethics: the creative orthodoxy of Buddhist monks in the Mongolian gold rush, Ethnos, 2016, Volume 81.

Humphrey, Caroline with Onon, Urgunge 1996 Shamans and Elders: Experience, Knowledge, and Power among the Daur Mongols, Oxford: Oxford University Press

Jacobs, Michael and Mazzucato, Mariana 2016 Rethinking Capitalism: Economics and Policy for Sustainable and Inclusive Growth, London: Wiley Press

Moretti, Daniele 2007 Ecocosmologies in the Making: New Mining Rituals in Two Papua New Guinea Societies, Ethnology, Vol 46, No. 4, 305-328.

Murphy, Daniel J. 2014 Booms and Busts: Asset Dynamics, Disaster, and the Politics of Wealth in Rural Mongolia, Economic Anthropology, 2014, 1: 104-123

Ortner, Sherry B. 2016 Dark anthropology and its others: Theory since the eighties, Hau: Journal of Ethnographic Theory 6 (1): 47-73

Robbins, Joel 2003 Properties of Nature, Properties of Culture: Possession, recognition, and the substance of politics in a Papua New Guinea Society, Suomen Anthropologi, 1/2003, 28, $9-28$.

Robbins, Joel 2013. "Beyond the suffering subject: Toward an anthropology of the good." Journal of the Royal Anthropological Institute 19 (3): 447-62.

Sneath, David 2001 Notions of rights over land and the history of Mongolian pastoralism, Inner Asia, Vol. 3, No.1, 41-59.

Roelvink, Gerda, St. Martin, Kevin and Gibson-Graham, J. K. 2015 Introduction: An Economic Politics for Our Times, Making Other Worlds Possible: Performing Diverse Economies, edited by Roelvink, Gerda, St. Martin, Kevin and Gibson-Graham, J. K, Minnesota: Minnesota University Press

Sneath, David 1993 Social Relations, Networks and social organisation in post-socialist rural Mongolia, Commission on Nomadic Peoples, no. 33

Sneath, David 2002 Custody and Property: Land, indigenous understanding, and the conceptual basis of development policy in pastoral Mongolia, C. Humphrey and R. Mandel (eds) Markets and Moralities: Ethnographies of Postsocialism, Routledge, pp. 191 -210. 
Tsing, Anna Lowenhaupt 2004 Friction: An Ethnography of Global Connection Princeton: Princeton University Press

Tsing, Anna Lowenhaupt 2015a The Mushroom at the End of the World: On the possibility of life in capitalist ruins, Princeton: Princeton University Press

Tsing, Anna 2015b Salvage Accumulation, or the Structural Effects of Capitalist Generativity, in Theorizing the Contemporary, Cultural Anthropology website, March 30, 2015. https://culanth.org/fieldsights/656-salvage-accumulation-or-the-structural-effects-ofcapitalist-generativity

Tumur-Ochir 2002 Land Law of Mongolia, Chapter one: general provisions. Article 5: Land Owners, Article 6: Land Possessors and Land Users, Chairman of the State Ih Hural of Mongolia, S. Tumur-Ochir, $7^{\text {th }}$ June 2002.

Zoljargal, M. 2013 Protest at the Government Palace leads to Arrests and Panic, UB Post, http://ubpost.mongolnews.mn/?p=6102, accessed $19^{\text {th }}$ September 2013.

\footnotetext{
i This quote is from her online article, which can be found here: Tsing, Anna. "Salvage Accumulation, or the Structural Effects of Capitalist Generativity." Theorizing the Contemporary, Cultural Anthropology website, March 30, 2015. https://culanth.org/fieldsights/656-salvage-accumulation-or-the-structural-effects-of-capitalistgenerativity

ii This quote is from their online article, which can be found here: Bear, Laura, Ho, Karen, Tsing, Anna and Yanagisako, Sylvia. "Gens: A Feminist Manifesto for the Study of Capitalism." Theorizing the Contemporary, Cultural Anthropology website, March 30, 2015. https://culanth.org/fieldsights/652-gens-a-feminist-manifestofor-the-study-of-capitalism

iii Usufruct is a term from European civil law, where the person has a right to enjoy the use and fruits of a property but not own it. 'Usufruct' means 'use of the fruit' (i.e. one has a right to enjoy the profit from land or capital, without legal title to the land or capital itself).

iv Also referred to as 'erleg elch', 'lus khangai', 'lus avdag', etc.

${ }^{v}$ Here we see that ' $[. .$.$] the land is not merely a national territory, a physical backdrop for human activity, or an$ enabling ecology. It is also a dynamic constituent in what makes people human. Recognizing the physical environment (baigal) as having life, feelings and agency, elaborate taboos inform people's engagement with the land (High and Schlesinger 2010: 290).

vi The date for the ceremony is often determined by astrological calculations, but if there is a drought, forest fires, or some adverse weather conditions, people may bring the date forward.

vii Worship at ovoos takes different forms according to the location of the ovoo and the type of deities attended to. In each smaller sub-district, there are several different ovoos. Some ovoos attract worship by men, others by local families or individuals, and some are places where the whole community gathers. Once a year, at the beginning of the summer, when people have settled at their summer pasture, people gather together for a ceremony at their local ovoo and offer dairy produce to honour masters of the land for the prosperity needed in life. The day is an occasion for those who share the same summer pastureland to meet and exchange news. viii In 1889, the Qing government established its first state-run gold mine in Northern Mongolia, and the prohibition on mining gold ended in 1899 with the rights given to the 'Mongolor' mining company (High and Schlesinger 2010). It is worth noting at this point that gold mining was something highly monitored during the Qing period. Then as now, mining sparked a fear of the purity of land and the fear of incoming miners' intrusive
} 
behaviors. Miners were punished, often violently, and there was intense anger against outsiders mining in Mongolia. This, and other activities that involved digging into the ground, could take away the 'luck' of the land or 'curse' the land and people (High and Schlesinger 2010: 292). Indeed 'failing to act respectfully, curses were unleased and misfortune was immanent' (2010: 292). Mongolian places known to contain gold were designated 'restricted areas' where mining and even trespassing was forbidden (High and Schlesinger 2010: 294). Very much as now, there was a concern with the idea that the land was to be kept clean (ariun) and protected from disturbing foreign presences. This relationship might provide echoes of similar cosmologies elsewhere (particularly as highlighted by one reviewer in Indonesia or Southeast Asia more generally), so that while there is no single kind of capitalism (or animism, for that matter), in their confrontation and merger with particular cosmological relations familiar tropes and arrangements arise.

${ }^{\text {ix }}$ Elsewhere, I have documented the way in which the landscape may be damaged through human interaction, but then 'healed' through further interactions (Empson 2011). The importance of human-nonhuman relationships is thus different from the kind of exclusionary logic of the environmental movement where places are separated off from human interaction and made into 'parks' to 'preserve' the environment.

${ }^{\mathrm{x}}$ However, Byambajav (2012) notes that many protected lands have been mined despite the law meant to preserve the integrity of Mongolia's environment.

${ }^{x i}$ This is a practice held to date back to the period of Chinggis Haan (e.g Burkhan Khaldyn).

xii It is possible that these were representatives of the 11 local River Movements who formed a trans-local coalition called the Homeland and Water Protection Coalition of River Movements in 2006 (see Byambajav forthcoming).

xiii Several groups, including Tsagaan Khass, Dayar Mongol, Gal Undesten and Huh Mongol, have sought alignment with environmentalist agendas, particularly against foreign mineral extraction in Mongolia. 